\title{
Verbal Prefixation and Metaphor: How Does Metaphor Interact with Constructions?*
}

\author{
Svetlana Sokolova
}

Abstract. This article argues that metaphorical and non-metaphorical content find different expression on the constructional level. The hypothesis is supported by two empirical case studies of the Russian Locative Alternation verbs, based on the data from the Russian National Corpus: the unprefixed verb sypat' 'strew' (which does not have an aspectual partner) and the unprefixed verb gruzit' 'load' and its three perfective partners with the prefixes na-, $z a-$, and $p o^{-}$. It is argued that metaphorical extensions of these Locative Alternation verbs have a strong relationship with elaborations (interactions between different constructions), on the one hand, and reduction (Locative Alternation constructions with a reduced or omitted participant), on the other. The results indicate differences in metaphorical behavior of different prefixes (even when they are used to form perfective partner verbs) and different constructions (some constructions are more often instantiated as metaphorical extensions than the other).

\section{Introduction}

In the cognitive linguistic view, metaphor is defined in terms of "crossdomain mapping" (Lakoff and Johnson 1980, Lakoff 1993: 203). More recent studies indicate that metaphors involve more than just mappings or bindings between two domains (or mental spaces) and should rather be treated as instances of blending among several domains (Fauconnier and Turner 2008). Another question is how such mapping or blending is expressed on the formal level. As noted in some recent corpus studies, there are frequently formal differences between meta-

\footnotetext{
* The author is extremely thankful to the members of the "Time is Space" research project Laura Janda, Tore Nesset, Mark Turner, Henning Andersen, Stephen Dickey, Östen Dahl, Vladimir Plungjan, Ekaterina Rakhilina, Julia Kuznetsova, Anastasia Makarova, and Anna Endresen for the inspiring discussions of the data and their useful comments on the first draft of the article.
}

Journal of Slavic Linguistics 21(1): \#\#-\#\#, 2013. 
phorical and literal uses of the same words, suggesting that metaphors have well-defined grammatical forms (Deignan 2005).

The issue that I address in this article is whether such differences are also attested at the level of constructions. Corpus research on metaphor usually starts with a metaphorical expression and examines which collocates and grammatical forms it combines with (Deignan 2005). By contrast, I will begin with specific constructions and analyze how they mark metaphorical uses. This approach will enable me to test whether metaphorical uses are marked on the constructional level. The constructions considered here are the Russian Locative Alternation Constructions (corresponding to John loaded the hay onto the truck vs. John loaded the truck with hay). An analysis of the Locative Alternation Constructions in the Russian National Corpus (www.ruscorpora.ru) indicates that their modifications are related to metaphor. These constructions can be modified in two ways: via elaboration and via reduction. Elaboration is the result of an interaction between the Locative Alternation Constructions and other constructions, as in example (1) below: ${ }^{1}$

$$
\begin{aligned}
& \text { (1) ...sypat' citatami } \quad \mathrm{v} \text { sobesednika. } \\
& \text { strew quotations } \text { s }_{I N S T} \text { in } \text { speaker }_{A C C} \\
& \text { '...strew quotations at the speaker.' }
\end{aligned}
$$

Reduction involves sentences where one of the participants in the Locative Alternation constructions (the one that is not in the direct object position) is missing, as in example (2) below:

(2) On... rešil zagruzit' svoego predannogo slušatelja. he $_{N O M}$ decided load his devoted listener $_{A C C}$

'He... decided to confuse his devoted listener.'

Both examples are metaphorical and will be discussed in section 3. I will show that in order to get a metaphorical extension, we do not

\footnotetext{
${ }^{1}$ All examples listed in the article were taken from the Russian National Corpus. The only exception is example (1), which comes from the Internet (http://www.vadimpanov.ru/ forum/viewtopic.php? $f=28 \& t=1544 \&$ start=60) and is presented here in order to illustrate the full version of the Hybrid construction that is not attested in my database from the corpus.
} 
simply fill the argument roles of a construction with linguistic units describing another domain, but often also perform structural changes.

Section 2 gives a brief overview of metaphor theory (2.1) and research done on the formal representations of metaphor (2.2). Section 3 describes my data and methods used. In section 4, I present two case studies of the Locative Alternation verbs: (i) the verb sypat' 'strew', illustrating a case of elaboration (4.1); and (ii) the verb gruzit' 'load' and its perfective partners nagruzit', zagruzit', pogruzit' 'load', discussing reduction (4.2). Conclusions are offered in section 5 .

\section{Metaphor Theory}

In classical theories of language beginning with Aristotle, it has been common to study metaphor as a matter of language in its relation to the cognitive mechanisms involved (see Turner 1995). The main contemporary approaches to metaphor follow roughly the same tendency, with more focus on one of the components: conceptual mechanisms pertinent to the human brain or the linguistic form that metaphor is characterized by. The subsections below give a brief overview of both tendencies, placing the present work in the overall picture of metaphor research.

\subsection{Conceptual Metaphor and Conceptual Integration}

Within contemporary theory of metaphor, the term "metaphor" has come to mean "a cross-domain mapping in the conceptual system" (Lakoff 1993: 203). The mapping in this case is a set of correspondences. For instance, a love relationship is often described in terms of a journey:

(3) a. Look how far we have come.

b. Our relationship has hit a dead-end street.

c. We may have to go our separate ways.

(Lakoff 1993: 206)

It follows from the frequency of such examples that metaphorical understanding of love in terms of a journey is part of the conceptual system underlying English. There are ontological correspondences, ac- 
cording to which entities in the domain of love (e.g., the lovers, the love relationship, etc.) correspond systematically to entities in the domain of a journey (the travellers, the vehicle, etc.). The LOVE IS A JOURNEY metaphor, or THE LOVE-AS-JOURNEY MAPPING, points out the following set of ontological correspondences:

(4) The lovers correspond to travellers.

The love relationship corresponds to the vehicle.

The lovers' common goals correspond to their common destinations on the journey.

Difficulties in the relationship correspond to impediments to travel.

(Lakoff 1993: 207)

To sum up, traditional metaphor involves three major elements: a source domain (such as journey), a target domain (love), and mapping relations across domains. Some recent studies on metaphor acknowledge that metaphors involve more than just mappings or bindings between two domains (or "mental spaces") (Fauconnier and Turner 2002 and 2008). Fauconnier and Turner (2008) discuss metaphor in terms of "integration networks" constructed by means of overarching general principles. They illustrate that conceptual products are never the result of a single mapping. What we have come to call "conceptual metaphors", like TIME IS SPACE, turn out to be mental constructions involving many spaces and many mappings in elaborate integration networks, cf. examples in (5-6):

(5) Three hours went by, and then we had dinner.

(6) *Three feet went by, and he was at the door.

(Fauconnier and Turner 2008: 5)

As established by metaphor theory, the new conceptualization of the domain of time is obtained through projection from space. For instance, the fact that time is measurable and stable comes from the domain of space. Examples (5) and (6) show that we have not merely projected units of measurement onto time, but also turned those units into moving objects. In the domain of space, a unit of measurement is not a moving object since these sorts of elements are incompatible. Yet, 
in the blend, we project onto a temporal experience both a unit of measurement and moving object from the domain of space, i.e., those elements that are incompatible in the domain of space become compatible in the domain of time.

Leaving further comparison of the Conceptual Metaphor Theory and the Conceptual Integration Theory outside the scope of this study, I demonstrate that both theories proceed from mapping relations among domains. From the perspective of both theories it is reasonable to ask whether metaphorical content has a different formal expression compared to non-metaphorical. As I will point out in section 4, linguistic representations of target domains in metaphorical uses of the Locative Alternation verbs are not absolutely parallel to their source domains. Yet, the major focus of this paper is on how metaphor reveals itself in metaphorical expressions. The fundamental tenet of Conceptual Metaphor Theory is that metaphor operates at the level of cognition, language being secondary to conceptual mappings. ${ }^{2}$ Taking the contributions of metaphor theory as my starting point, I will draw the attention from cognition back to linguistic expressions, showing that linguistic representations of metaphor are more structured than previously believed.

\subsection{Formal Metaphor Representations}

In recent years metaphor researchers have begun to analyze naturally occurring language data (Deignan 2005, Stefanowitsch 2006, Steen 2007, Steen et al. 2010). Some collective research has been done on developing a method for linguistic metaphor identification (Steen et al. 2010). According to findings of the Pragglejaz Group (Steen 2007: 3), an important characteristic of a metaphorical sense as opposed to a basic sense is that this "contextual meaning contrasts with the basic meaning but can be understood in comparison with it". The Metaphor Identification Procedure, introduced by the Pragglejaz Group, helps to discover active and dead metaphors.

\footnotetext{
2 "What constitutes the love as a journey metaphor is not any particular word or expression. It is the ontological mapping across conceptual domains, from the source domain of journeys to the target domain of love. The metaphor is not just a matter of language, but of thought and reason. The language is secondary" (Lakoff 1993: 208).
} 
Some recent corpus studies investigate formal differences between metaphorical and literal uses of the same words, showing that the grammatical forms of metaphors are fairly restricted. Deignan (2005) presents a corpus study of nouns denoting animals and their mappings onto human characteristics (dog, fox, lion, etc.). Her study shows that the grammatical behavior of metaphors is different from that of the target domain (for instance, derived forms foxy or kittenish are commonly not attested for the source domain units and are used only metaphorically).

The Metaphor Identification Procedure introduced in corpus studies undoubtedly helps us in solving certain applied tasks (lexicographic and corpus-driven) but leaves several important questions open. First of all, this approach is driven by lexical units: we look at literal and metaphorical uses of certain words, which leaves some of the information out of the picture. Second, this procedure is mostly interested in factors that could be easily operationalized, such as grammatical forms and morphology but overlooks constructions since often they require manual tagging. Finally, this approach centers on linguistic expressions and does not discuss how these expressions are related to cognition.

In the present paper, I try to address all the issues mentioned above with special emphasis on the first two. I narrow down the scope of the study by looking at constructions. The hypothesis that I entertain here is that in order to get a metaphorical extension, we do not simply fill the argument roles of a construction with linguistic units describing another domain (as, for instance, suggested in Marantz 1984, cf. the literal use kill a man vs. the figurative use kill a bottle, kill an hour), but often also perform some structural changes. I show that constructions in metaphorical and non-metaphorical uses behave differently, which might shed additional light on some mismatches observed between the source and the target domains (cf. Fauconnier and Turner 2008).

Although I agree with Lakoff's contention that "the locus of metaphor is not in language at all, but in the way we conceptualize one mental domain in terms of another" (Lakoff 1993: 203), I will try to illustrate that metaphorical expressions in themselves require further investigation. 


\section{Data and Methodology}

Corpus research on metaphor usually starts with a metaphorical expression and examines which collocates and grammatical forms it goes with (Deignan 2005). The present study begins with particular constructions and analyzes what kind of metaphorical uses they have. The constructions of interest are the Locative Alternation constructions. My empirical study examines the constructional profiles of the Russian verb sypat' 'strew' and the verb gruzit' 'load' and its prefixed counterparts as evidenced by data from the Russian National Corpus. I first describe how the data was extracted and coded and then define the term "constructional profile".

\subsection{Russian Locative Alternation Constructions and their Extensions}

As mentioned earlier, the Locative Alternation is represented by two constructions: Theme-Object, as in examples (7) and (8), and Goal-Object, as in example (9). ${ }^{3}$ The two constructions differ in which of the participants is marked as the direct object: the Theme (i.e., elements like hay), or the Goal (i.e., elements like truck). In both constructions the direct object is consistently coded in Russian with the bare Accusative case, while the other participant can be expressed via different forms.

The Theme-Object construction encodes the Goal via a prepositional phrase (usually with prepositions $v$ 'into' and $n a$ 'onto') with a noun in the Accusative case, as illustrated in examples (7) and (8).

(7) Potom s pomoščju avtokrana predpolagalos' gruzit' then with help INST crane ${ }_{\text {GEN }}$ was-supposed load $_{I N F}$

brevna na baržu.

$\log s_{A C C}$ on barge ${ }_{A C C}$

'Then, with the help of the crane, we were supposed to load the logs onto the barge.'

\footnotetext{
${ }^{3}$ This terminology is taken form Nichols 2008.
} 
(8) Ne toropites' sypat' pesok v korobku. not hurry strew sand $A C C$ into box bCC

'Don't hurry with pouring the sand into the box.'

In the Goal-Object construction the other participant is coded by the Instrumental case without a preposition:

(9) On sodrogalsja, slušaja o tom, kak gruzili he $_{N O M}$ shuddered hearing about that ${ }_{L O C}$ how loaded

$\begin{array}{lll}\begin{array}{l}\text { vagony } \\ \text { wagons }_{A C C}\end{array} & \begin{array}{l}\text { detskimi } \\ \text { childrens' }^{\prime}\end{array} & \begin{array}{l}\text { trupami. } \\ \text { corpses }_{I N S T}\end{array}\end{array}$

'He shuddered hearing about how they loaded wagons with childrens' corpses.'

Both the Theme-Object and the Goal-Object construction can have metaphorical extensions, i.e., they can be instantiated as metaphorical contexts where the semantic class of the participants is modified from more concrete to more abstract. ${ }^{4}$ For instance, human beings can serve as the metaphorical CONTAINERS (Goal) for information that represents metaphorical CONTENTS (Theme), as in example (10) below (HUMAN IS A COMPUTER metaphor):

(10) Ax, vam interesny podrobnosti iz žizni oh you $_{D A T}$ interesting details $s_{N O M}$ from life GEN zvezd? Radi boga, Andrej Maksimov "zagruzit" pop stars ${ }_{G E N}$ Sake $\operatorname{god}_{G E N}$ Andrej Maksimov NOM $_{\text {will-load }}$ vas ètoj informaciej. you $_{A C C}$ this information ${ }_{I N S T}$

'Oh, you are interested in the details of the life of our pop stars? No problem, Andrej Maksimov will provide you with this information.'

\footnotetext{
4 In this article, I use the term "extension" the same way as Goldberg (1995) and Croft and Cruse (2004). According to Goldberg (1995), metaphorical extensions are a typical representation of polysemy links.
} 
Illustrative examples of major metaphors attested for the 'load' verbs are given below:

\section{Goal:HUMAN + Theme:INFORMATION}

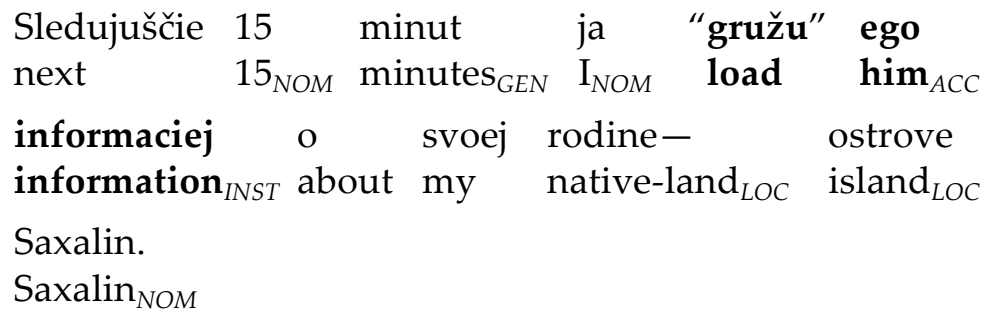

'In the next 15 minutes, I loaded him with information about my native land - the land of Island of Saxalin.'

[Dmitrij Kovalenin. Marafonec Murakami (2002) //

“Domovoj", 2002.11.04]

(12) Xačatrjan ne sderžal neudovolstvija ot togo, Xačatrjan $_{N O M}$ not suppressed discontent diEN $_{\text {from that }}$ fEN čto Kolomnin, kotorogo on toropilsja "nagruzit"” that Kolomnin NOM $_{\text {whom }}$ ACC he hOM $_{\text {hurried load }}$ informaciej, beskonečno otvlekaetsja. information $_{I N S T}$ endlessly gets-distracted 'Xačatrjan didn't hide his discontent that Kolomnin, whom he was trying to quickly fill with information, got distracted all the time.'

[Semen Daniljuk. Biznes-klass (2003)]

\section{Goal:HUMAN + Theme:WORK}

(13) Neobxodim byl professional, kotoryj by stal needed $_{N O M}$ was professional ${ }_{N O M}$ who $_{N O M}$ would become "parovozom", nagruzil sebja vsej rabotoj. locomotive $_{I N S T}$ load self $_{A C C}$ all work $_{I N S T}$

'They needed a work horse, someone who would load himself up with all the work' 
(14) Zasedanie Gossoveta po kul'ture zagruzit meeting $_{N O M}$ State-Council $_{G E N}$ on culture DAT $_{\text {will-load }}$ rabotoj sotrudnikov Minsterstva kul'tury na bližajšie work $_{I N S T}$ members $_{A C C}$ Ministry $_{G E N}$ Culture $_{G E N}$ for nearest neskol'ko let. few $_{A C C} \quad$ years $_{G E N}$

'The agenda of the State Council on Culture will keep the members of the Ministry of culture busy for several years.'

\section{Goal:ELECTRONIC DEVICE + Theme:FILE}

(15) Každyj, kto rassčityvaet $\mathrm{v}$ Afinax zapustit' v each $_{N O M} w_{\text {ho }}$ NOM intends in Athens $s_{L O C}$ launch into

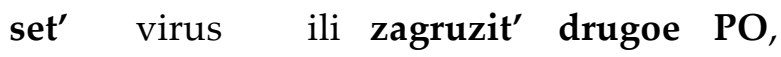
net $_{A C C}$ virus $_{A C C}$ or load another software ${ }_{A C C}$ smožet ubedit'sja, čto dostup $\mathrm{k}$ diskovodam, a will-be-able see that access $_{N O M}$ to disk-drives ${ }_{D A T}$ and takže $k$ USB-portam na $P K$ i serverax zakryt. also to USB-ports $s_{D A T}$ on $\mathrm{PC}_{L O C}$ and servers ${ }_{L O C}$ closed $_{N O M}$ 'Everybody with the intention to launch a virus or upload software onto the net in Athens will see that the access to the disk drives as well as to the USB ports on PCs and servers is closed.'

\section{Goal:WORDS + Theme:MEANING}

(16) Posle simvolistov... slovo utratilo ves;

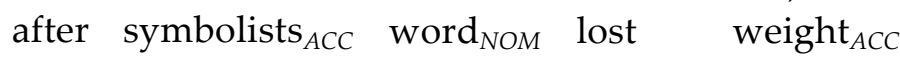
akmeisty zaxoteli bylo ego nagruzit' - no polučalas' acmeists $_{N O M}$ wanted was it iCC $_{\text {load but came-out }}$ libo priključenčeskaja proza, libo nesvjaznoe, either adventurous prose $\mathrm{NOM}_{\mathrm{N}}$ or incoherent xot' $^{\prime}$ i angel'skoe bormotanie... although and angel-like $\operatorname{murmur}_{N O M}$ 'After symbolists... the word lost its significance, acmeists wanted to fill it with a new meaning but this attempt ended up either as adventurous prose or as an incoherent, though angelic murmur...' 


\section{Goal:FACILITY + Theme:WORK}

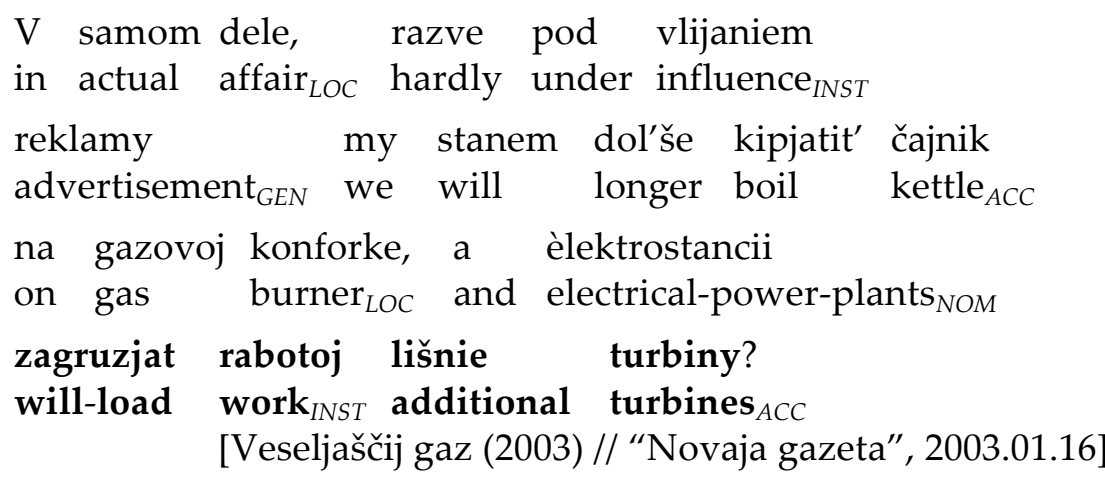

'Really, is it possible that due to the advertisement we will boil the kettle longer on a gas burner or that the electrical powerplants will provide additional turbines with work?'

Furthermore, metaphorical and non-metaphorical uses can be structurally modified in two different ways: via elaboration and via reduction. Elaboration occurs when the Locative Alternation Constructions interact with other constructions. ${ }^{5}$ A common instance of elaboration within the Locative Alternation is what I will call a "hybrid construction", where none of the participants is expressed as a direct object in the Accusative case (example 18):

$$
\begin{aligned}
& \ldots \text { veter... syplet snegom v okna. } \\
& \text { wind }_{N O M} \text { strews snow } I N S T \text { in windows } \\
& \text { '...the wind... strews snow into the windows.' }
\end{aligned}
$$

The term "hybrid" is used to emphasize that in sentences like (18) we are dealing with both participants, the Theme and the Goal, but neither of them appears as a direct object. This might be a signal that the focus of the sentence is neither on the Theme nor on the Goal. In both the Theme-Object and the Goal-Object constructions the Theme is a certain quantity of the substance that is being moved and the Goal is

\footnotetext{
5 "Elaboration" is a provisional term that is used here in order to distinguish interactions between constructions from "extensions" and "reduced" versions of a construction, which are still instances of the same construction.
} 
the endpoint of the movement. Thus, by adding the prefix $z a$ - we get a resultative reading:

\section{Theme-Object construction:}

$\begin{array}{llll}\text { (19) Zasyp'te jagody } & \mathbf{v} \text { kastrjulju. } \\ \text { strew } & \text { berries }_{A C C} \text { in } \text { casserole }_{A C C}\end{array}$

'Put the berries into the casserole.'

\section{Goal-Object construction:}

\section{Zasyp'te klubniku saxarom. \\ strew strawberries ${ }_{A C C}$ sugar $_{I N S}$ \\ 'Cover the strawberries with sugar.'}

In the case of (19), the berries are in the casserole, and in the case of (20), the strawberries are completely covered with sugar. If we add the same prefix to the verb sypat' 'strew' in the Hybrid construction, the attained meaning is ingressive, not resultative:

$$
\begin{array}{cllll}
\ldots \text {...veter... } & \text { zasyplet } & \text { snegom } & \mathbf{v} & \text { okna. } \\
\text { wind } & \text { za-strews } & \text { snow }_{I N S} & \text { in } & \text { windows } \\
A C C
\end{array}
$$

'...the wind... will start strewing snow into the windows.'

Thus, the Theme-Object construction places the focus on the Theme, the Goal-Object construction on the Goal, and the Hybrid construction on none of the above. For the Locative Alternation verbs I have attested an interaction between elaboration, as in the Hybrid construction, and metaphor (see example (1) repeated below):

\section{Metaphorical Hybrid construction:}

(1) ...sypat' citatami $\quad \mathbf{v}$ sobesednika. strew quotations INST $_{\text {in }}$ speaker $_{A C C}$

'strew quotations at the speaker.'

Such contexts usually present a person as the Agent and jokes, quotations, words, curses, proposals, numbers, terms, etc., as the Theme, which is directed at a listener who represents the Goal. Such 
cases can be interpreted in terms of a HUMAN IS A FOUNTAIN metaphor, where the subject splashes all kinds of information around him like a fountain splashes water:

$$
\begin{aligned}
& \text {...cvetnoj fontan } \begin{array}{l}
\text { syplet } \text { bryzgami... } \\
\text { colorful fountain } \\
\text { sOM } \\
\text { strews } \text { splashes }_{I N S T}
\end{array} \\
& \text {.... a colorful fountain splashes...' }
\end{aligned}
$$

"Hybrid" constructions will be discussed in more detail in section 4.1.

Reduction involves sentences where one of the participants in the Locative Alternation constructions (the one that is not in the direct object position) is missing. Most cases with an omitted Theme or Goal argument are instances of ellipsis since the missing participant is perceived from the context. Examples (23) and (24) below illustrate a Theme-Object construction with a missing Goal and a Goal-Object construction with a missing Theme:

\section{Theme-Object construction with a missing Goal:}

(23) No uže v bližajšee vremja ožidaetsja podxod but already in nearest time ${ }_{A C C}$ is-expected arrival ${ }_{N O M}$ sudov obščim tonnažem 780 tys. tonn. vessels $_{\text {GEN }}$ total tonnage INST 780 thousand tons ${ }_{G E N}$

Tol'ko zagruzit' ugol' budet problematično, poskol'ku just load $\mathbf{c o a l}_{A C C}$ will-be problematic since iz-za moroza on prevratilsja $\mathrm{v}$ glyby. due-to frost $_{G E N} i_{\text {NOM }}$ turned into blocks ${ }_{A C C}$

'But already in the nearest future we expect the arrival of vessels with total tonnage of 780 thousand tons. Just getting the coal loaded will be problematic since due to the cold it has turned into blocks.'

\section{Goal-Object construction with a missing Theme:}

(24) Nikolaj... očen' skoro upravilsja s pokupkami, Nikolaj $_{\text {NOM }}$ very soon finished with purchases INST nagruzil podvody i, poka mužiki kormili loaded wagon $_{A C C}$ and while $\operatorname{men}_{N O M}$ fed 
'Nikolaj... was very soon done with the purchases, loaded the wagon, and while the men were feeding the horses, he went slouching about the rows.'

However, corpus examples also show cases of interaction between reduction and metaphor as presented in example (25):

\section{Metaphorical Goal-Object construction with a missing Theme:}

$$
\begin{aligned}
& \text { On... rešil zagruzit' svoego predannogo slušatelja. } \\
& \text { he }_{N O M} \text { decided load his devoted listener }{ }_{A C C}
\end{aligned}
$$

In example (25), human beings serve as the metaphorical CONTAINERS for information that represents metaphorical CONTENTS. Such examples should be distinguished from pure cases of ellipsis since the omission of the second participant is highly conventionalized. The interaction between metaphor and reduction will be further discussed in section 4.2.

The use of prefixes in Russian presents a challenge for research on the Locative Alternation in that it introduces a more complicated system of alternating verbs. Considering the interaction between prefixes and locative constructions, three groups of alternating verbs can be singled out:

(i) verbs that can alternate in both unprefixed and prefixed forms (verbs like gruzit' 'load');

(ii) verbs that do not alternate when unprefixed but are used in both constructions with certain prefixes (verbs like lit' 'pour', and sypat' 'strew, scatter', cf. za-lit' benzin ${ }_{A C C} v$ bak $k_{A C C}$ 'za-pour gasoline into the tank'; $z a$-lit' $b_{a k_{A C C}}$ benzinom $_{I N S T}$ ' $z a$-fill the tank with gasoline');

(iii) verbs that do not alternate in unprefixed forms and can be used either in Theme-Object or Goal-Object construction depending on the prefix (verbs like stavit' 'put, place', cf. po-stavit' 'put, place' vs. ob-stavit' 'furnish (with)'). 
As follows from this overview, the verb sypat' 'strew' does not alternate without a prefix. Yet, in addition to the Theme-Object construction (example 8) and this verb is also attested in hybrid constructions; see example (18) above.

Thus, my major interest lies in the extensions of constructions within the group of Locative Alternation verbs. Since the basic mechanisms of extension are elaboration and reduction, I have picked two sets of verbs that can well illustrate these phenomenona. Elaboration will be observed in the case study of sypat' 'strew' and reduction in the case of the 'load' verbs (gruzit', nagruzit', zagruzit', pogruzit'). ${ }^{6}$

\subsection{Database Description and Methodology}

For the purpose of this study, I constructed a database based on the Modern subcorpus (1950-2009) of the RNC, which contains 98 million words. I extracted examples from this subcorpus for the unprefixed verb sypat' 'strew' and the verb gruzit' 'load' and its perfective counterparts (with the prefixes $n a-, z a-, p o-$ ). To exclude the author as one more relevant factor, the database was cleaned so that there is only one example for each verb from any single author selected via randomization. The same procedure was performed for all verb forms and in addition passive participles received a separate mark. Passive participles represent an interaction between the Locative Alternation constructions and the passive construction, and this interaction has a significant impact on the distribution of the Locative Alternation constructions. ${ }^{7}$ For this reason, I leave passive forms beyond the scope of this study. This yields 1186 examples that are considered in the present article: 328 examples with active forms of the verb sypat' 'strew' and 858 examples with active forms of the four 'load' verbs.

The examples thus accumulated were manually coded for the Locative Alternation constructions as Theme-Object vs. Goal-Object. The

\footnotetext{
${ }^{6}$ According to two dictionaries (Evgen'eva 1999 and Ožegov and Švedova 2001) and a list (Cubberly 1982), the verb gruzit' has three perfective counterparts, with the prefixes $n a-, z a-, p 0^{-}$, all of which can alternate. Since all of them are glossed as 'load' I refer to them as the 'load' verbs.

7 The Locative Alternation involves two objects, Theme and Goal, both of which can be in focus. The passive construction restricts the focus to just one participant. Where active forms show a preference for one construction over the other, this preference is further exaggerated in the presence of passive forms.
} 
breakdown and analysis of these data are presented in 4.1 for the nonpassive forms of the verb sypat 'strew' and in 4.2 for the non-passive forms of the 'load' verbs.

The method used in the present study is constructional profiling, i.e., comparing "the relative frequency distribution of the constructions that a word appears in" (Janda and Solovyev 2009: 367). This frequency distribution is based on corpus data. Constructional profiling takes the word as the point of departure and, in a sense, is the inverse of the collostructional methodology (Stefanowitsch and Gries 2003, 2005), which takes the construction as the point of the departure and asks what words occur in the construction.

\section{Analysis}

This section presents two case studies that address the interaction between metaphor and elaboration, on the one hand, and metaphor and reduction, on the other. The former is discussed in the case study of sypat' 'strew', the latter in the case study of the 'load' verbs.

\subsection{Case Study 1: sypat' 'strew'}

As mentioned in the previous section, the verb sypat' 'strew' belongs to the class of verbs that do not alternate when unprefixed but are used in both constructions with certain prefixes, for instance, the prefix $z a-$; see examples (19-20) repeated below:

\section{Theme-Object construction:}

\section{(19) Zasyp'te jagody v kastrjulju.} strew berries $_{A C C}$ in casserole c $_{A C C}$

'Put the berries into the casserole.'

\section{Goal-Object construction:}

$$
\begin{array}{lll}
\begin{array}{l}
\text { Zasyp'te } \\
\text { strew }
\end{array} & \text { klubniku } & \text { saxarom. } \\
\text { strawberries }_{A C C} & \text { sugar }_{I N S T}
\end{array}
$$

'Cover the strawberries with sugar.' 
However, the unprefixed verb sypat' is limited to the Theme-Object construction (example (8) repeated here), the Decausative construction (example (26)), and the Hybrid construction (example (18) repeated).

\section{Theme-Object construction:}

(8) Ne toropites' sypat' pesok v korobku. not hurry strew sand sCC $_{\text {into }}$ box $_{A C C}$

'Don't hurry with pouring the sand into the box.'

\section{Decausative construction:}

(26) Sneg sypet besprestanno.

snow $_{N O M}$ strews constantly

'The snow pours constantly.'

\section{Hybrid construction:}

...veter... syplet snegom $\mathbf{v}$ okna.

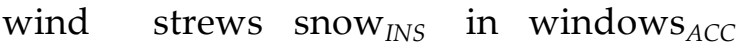

'...the wind... strews snow into the windows.'

The Hybrid construction in (18) represents a blend between the Theme-Object construction and the Decausative construction. In the Decausative construction, the subject is not a prototypical agent; for this reason such sentences often describe precipitation. In the Hybrid construction, the agentive properties of the subject are reduced, so that it often refers to an uncontrollable or an involuntary action.

Metaphorical extensions are attested for all the three constructions of the verb sypat'. I illustrate them in examples (27-30) below:

\section{Metaphorical Theme-Object construction:}

(27) Ne syp' mne sol' na ranu. not strew me $_{D A T}$ salt ${ }_{A C C}$ on wound $_{A C C}$

'Don't rub salt into my wounds.' 
(28) Takie posobija- ne manna nebesnaja, kotoruju such allowances ${ }_{N O M}$ not manna heavenly ${ }_{N O M}$ which $_{A C C}$ syplet na golovy svoix sograždan gosudarstvo. strews on heads $A C C$ own citizens $_{G E N}$ state $_{N O M}$

'Such allowances are not manna from heaven which the state strews on the heads of its citizens.'

\section{Metaphorical Decausative construction:}

(29) I voobšče, syp' otsjuda, istorik! and well strew from-here historian NOM

'And well, get lost, you, historian!'

Unlike non-metaphorical uses of the Decausative construction (see example (26)), the subject in example (29) is agentive. Thus, in (29) the verb sypat' 'strew' is reinterpreted as a motion verb.

\section{Metaphorical Hybrid construction:}

(30) On stal ugrjumym, sypal zlymi šutkami. he ${ }_{N O M}$ got gloomy INST $_{\text {strew spiteful jokes }}$ INST

'He became gloomy, started telling spiteful jokes.'

Quite remarkably, the major portion of metaphorical uses of the verb sypat' 'strew' occurs in the Hybrid construction. Such contexts usually present a person as a subject and jokes, quotations, words, curses, proposals, numbers, terms, etc., as the object in the Instrumental case (which corresponds to the Theme). The Goal as a rule is omitted but quite often is present in the context indirectly or is expressed by other means (not as a preposition with the Accusative case). Examples (31-32) illustrate metaphorical hybrid constructions with the Goal which is mentioned in the preceding or the following context:

(31)

$\begin{array}{lllll}\begin{array}{l}\text { Zato } \mathrm{v} \text { svoem } \\ \text { but in own }\end{array} & \begin{array}{l}\text { isstuplenii } \\ \text { frenzy }_{L O C}\end{array} & \begin{array}{l}\text { oni } \\ \text { they }_{N O M}\end{array} & \begin{array}{l}\text { slovooxotlivy }_{\text {talkative }} \text { ne } \\ \text { not }\end{array} \\ \mathrm{v} \text { meru: } & \text { tol'ko } \mathrm{i} & \text { sypljut } & \text { proročestvami } & \mathrm{i} \\ \text { in measure } & \text { sOC } & \text { only and strew } & \text { prophesies }_{I N S T} \text { and }\end{array}$


(31) predskazanijami vypalivaja ix sobravšimsja predictions $_{I N S T}$ out-shooting them ${ }_{A C C}$ gathered $_{D A T}$

rjadom ljudjam.

near people DAT

'But in their frenzy they are excessively talkative: constantly pouring prophesies and predictions, shooting them at the people around them.'

(32) On sypal nacelennymi $\mathrm{v}$ tot ili inoj adres he $_{N O M}$ strewed pointed $d_{I N S T}$ in this or that address ${ }_{A C C}$ èpigrammami. epigrams $_{I N S T}$

'He was bursting with epigrams addressed to certain people.'

On the Internet it is possible to find the examples with the overt expression of the Goal, as in (1) repeated below:

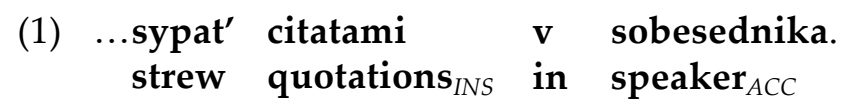

'...strew quotations at the speaker.'

The distribution of metaphorical and non-metaphorical uses of the verb sypat' 'strew' in the Russian National Corpus is presented in Table 1 and Figure 1 below:

Table 1: The Locative Alternation within the Verb Sypat' 'Strew'

\begin{tabular}{lccccc}
\hline & \multicolumn{2}{c}{ non-metaphorical } & \multicolumn{2}{c}{ metaphorical } & \\
\cline { 2 - 5 } & $\begin{array}{l}\text { raw } \\
\text { frequency }\end{array}$ & $\begin{array}{l}\text { relative } \\
\text { frequency }\end{array}$ & $\begin{array}{l}\text { raw } \\
\text { frequency }\end{array}$ & $\begin{array}{l}\text { relative } \\
\text { frequency }\end{array}$ & \\
\hline Theme-Object & 118 & $75 \%$ & 39 & $25 \%$ & 157 \\
Hybrid & 6 & $5 \%$ & 119 & $95 \%$ & 125 \\
Decausative & 39 & $85 \%$ & 7 & $15 \%$ & 46 \\
Total & 163 & $49.7 \%$ & 165 & $50.3 \%$ & 328 \\
\hline \hline
\end{tabular}




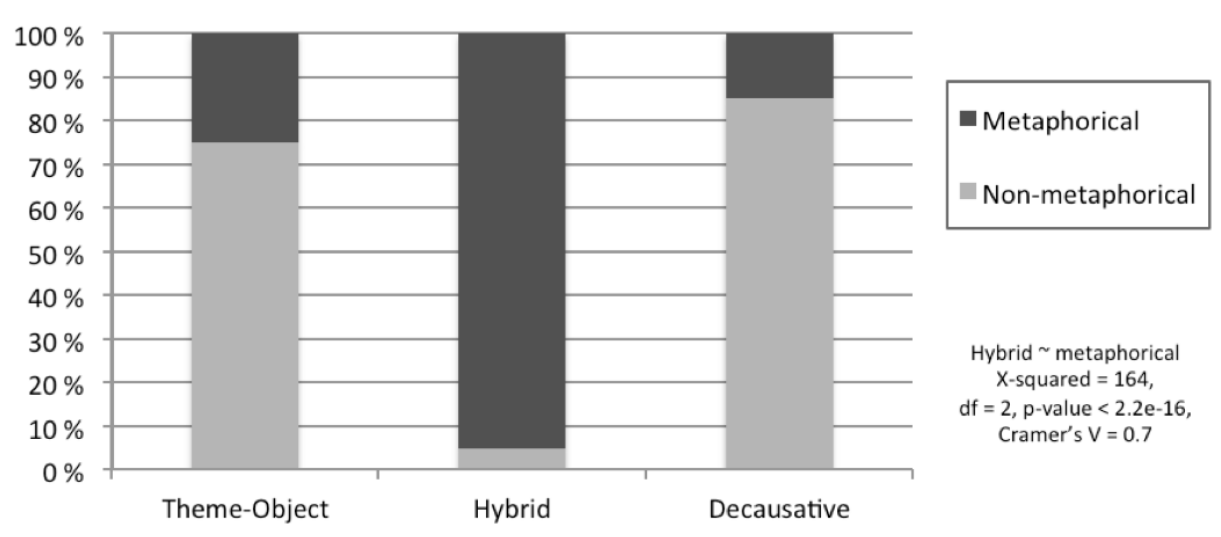

Figure 1. The locative alternation within the verb sypat' 'strew'

As follows from Table 1, within the Hybrid construction, metaphorical extensions constitute $95 \%$ of all attestations. Furthermore, $72 \%$ of all metaphorical uses of the verb sypat' 'strew' are attested in the Hybrid construction.

Thus, the data from the verb sypat' 'strew' supports the idea that metaphorical uses are marked by constructional restructuring: metaphorical uses of sypat' mostly occur in Hybrid constructions. Hybrid constructions present agents in a less agentive manner and the action as less directional. Furthermore, the target domain seems to retain some of its initial qualities: jokes, words, etc., are presented as intrinsic parts of the source (which in the case of metaphorical sypat' is usually a person). Thus, the situation of 'strewing jokes or words' becomes more similar to the situation of emanation rather than a dislocation of objects or dry substances.

\subsection{Case Study 2: gruzit' 'load'}

The 'load' verbs that I consider in this section are the unprefixed verb gruzit' and its three prefixed counterparts nagruzit', zagruzit', pogruzit'. All four verbs are glossed as 'load' (Ožegov and Švedova 2001). Below I will show that, although the prefixes $n a-, z a-$, and po- with the verb gruzit' 'load' do not provide a meaning difference that can be captured with English glosses, they affect the contexts preferred by the verb.

The uses of gruzit' are compatible with both the Theme-Object and the Goal-Object constructions (see examples (3) and (5) above). The 
distribution of the non-passive forms of gruzit' 'load' and its perfective counterparts across the Locative Alternation constructions is summarized in Table 2 and Figure 2 below:

Table 2. Locative Alternation within the Non-Passive Forms of the Russian 'load' Verbs

\begin{tabular}{lccccc}
\hline \multirow{2}{*}{$\begin{array}{l}\text { Active } \\
\text { forms }\end{array}$} & \multicolumn{2}{c}{$\begin{array}{c}\text { Theme-Object } \\
\text { construction }\end{array}$} & \multicolumn{2}{c}{ Goal-Object construction } & \multirow{2}{*}{ Total } \\
\cline { 2 - 5 } only & $\begin{array}{l}\text { raw } \\
\text { frequency }\end{array}$ & $\begin{array}{l}\text { relative } \\
\text { frequency }\end{array}$ & $\begin{array}{l}\text { raw } \\
\text { frequency }\end{array}$ & $\begin{array}{l}\text { relative } \\
\text { frequency }\end{array}$ & \\
\hline gruzit' $^{\text {nagruzit' }}$ & 180 & $72 \%$ & 69 & $28 \%$ & 249 \\
nagruzit' & 34 & $23 \%$ & 113 & $77 \%$ & 147 \\
pogruzit' & 94 & $45 \%$ & 114 & $55 \%$ & 208 \\
Total & 253 & $99.6 \%$ & 1 & $0.4 \%$ & 254 \\
\hline \hline
\end{tabular}
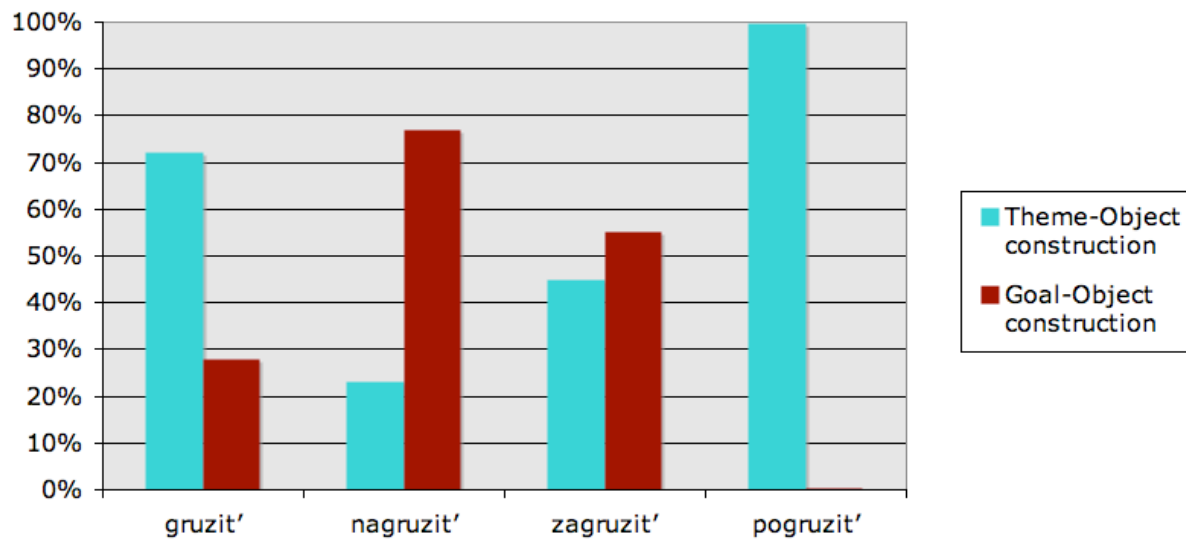

Figure 2. Locative alternation within the non-passive forms of the Russian 'load' verbs

In Figure 2, we see clear differences among the four 'load' verbs. The unprefixed gruzit' strongly prefers the Theme-Object construction. The prefixed verb nagruzit' is nearly the mirror image, preferring the Goal-Object construction. This preference of nagruzit' for focusing on the Goal may have to do with the SURFACE meaning of na-. Pogruzit' is almost exclusively restricted to the Theme-Object construction, suggesting a focus on the Theme that is loaded rather than the place 
where the load ends up. Zagruzit' is the only verb that shows an almost even distribution across the two constructions. ${ }^{8}$ A more elaborate analysis of the examples indicates that this could be due to the number of additional metaphorical uses that this verb has in the Goal-Object construction. ${ }^{9}$ Of the three prefixed counterparts to the verb gruzit' 'load', zagruzit' is more often used metaphorically: zagruzit' has 39\% metaphorical uses, while nagruzit' and pogruzit' have $25 \%$ and $11 \%$, respectively (see Table 3 and Figure 3). The major metaphorical extensions of zagruzit' involve a "person" (Goal), who serves as the metaphorical CONTAINER, and "information" or "work" (Theme), which represent metaphorical CONTENTS, as shown in examples (10) and (14) repeated here:
(10) Ax, vam interesny podrobnosti iz žizni oh you yAT $_{\text {interesting details }}$ NOM from life GEN zvezd? Radi boga, Andrej Maksimov "zagruzit" pop stars ${ }_{G E N}$ Sake $\operatorname{god}_{G E N}$ Andrej Maksimov vas ètoj informaciej. you $_{A C C}$ this information ${ }_{I N S T}$

'Oh, you are interested in the details of the life of our pop stars? No problem, Andrej Maksimov will provide you with this information.'

\footnotetext{
8 The differences among the four 'load' verbs at different levels, i.e., the distribution of constructions, active vs. passive forms, and the number of reduced constructions (excluding the factor of metaphor which is considered in more detail in this article), were found to be significant in a logistic regression analysis (see Sokolova, Lyashevskaya, and Janda 2012).

${ }^{9}$ I am particularly thankful to Stephen Dickey for his suggestion to attribute the metaphoric propensity of za- to its subjective meanings of deviance. If we assume that za- is combined with gruzit' to create a verb with an ordinary meaning ('load smth with smth'), then the source for the metaphorical uses of za- is the fact that more subjective meanings of za- (e.g., 'put/end in a deviant state') would be accessible to the new derived verb, allowing further blending. The metaphorical potential of zagruzit' 'load' is motivated by the semantic network of za- but is not solely based on the meaning of deviance. Frequent metaphorical uses with za- include not only negative but also positive contexts like zagruzit' zavod rabotoj 'load the factory with work', which are most likely motivated by other meanings of za-, such as 'filling'. For more details on metaphorical patterns of the Russian 'load' verbs, see Sokolova 2012.
} 
(14) Zasedanie Gossoveta po kul'ture zagruzit meeting $_{N O M}$ State-Council $_{G E N}$ on culture DAT $_{\text {will-load }}$

rabotoj sotrudnikov Minsterstva kul'tury na bližajšie work $_{I N S T}$ members $_{A C C}$ Ministry $_{G E N}$ Culture $_{G E N}$ for nearest

neskol'ko let.

few $_{A C C} \quad$ years ${ }_{G E N}$

'The agenda of the State Council on Culture will keep the members of the Ministry of culture busy for several years.'

Table 3. Relative Frequencies of Metaphorical Contexts for the Verb gruzit' 'Load' and Its Perfective Counterparts

\begin{tabular}{lccccc}
\hline \multirow{2}{*}{$\begin{array}{l}\text { Active } \\
\text { forms only }\end{array}$} & \multicolumn{2}{c}{ non-metaphorical } & \multicolumn{2}{c}{ metaphorical } & \\
\cline { 2 - 4 } & $\begin{array}{l}\text { raw } \\
\text { frequency }\end{array}$ & $\begin{array}{l}\text { relative } \\
\text { frequency }\end{array}$ & $\begin{array}{l}\text { raw } \\
\text { frequency }\end{array}$ & $\begin{array}{l}\text { relative } \\
\text { frequency }\end{array}$ & Total \\
\hline gruzit' & 186 & $75 \%$ & 63 & $25 \%$ & 249 \\
nagruzit' $_{\text {zagruzit' }}^{110}$ & 127 & $75 \%$ & 37 & $25 \%$ & 147 \\
pogruzit' & 227 & $61 \%$ & 81 & $39 \%$ & 208 \\
\hline \hline
\end{tabular}

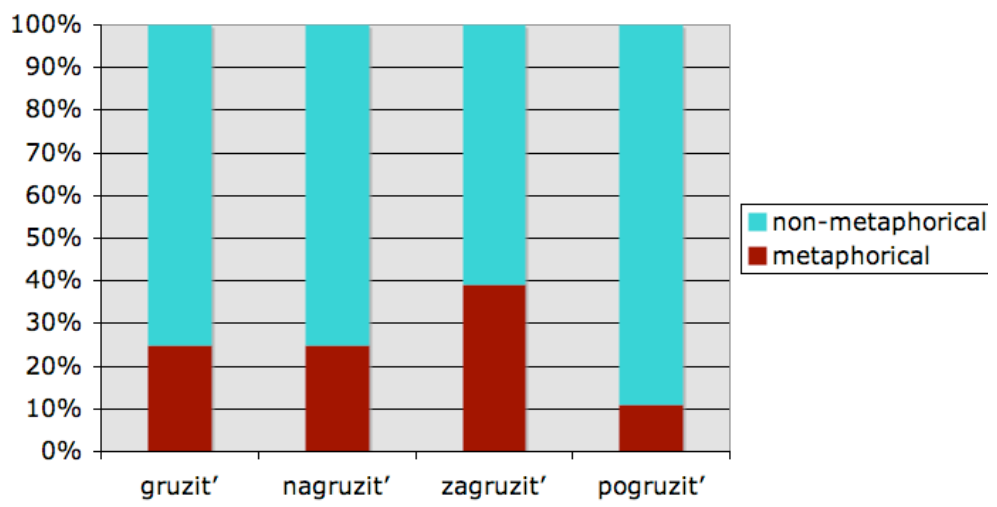

Figure 3. Relative frequencies of metaphorical contexts for the verb gruzit' 'load' and its perfective counterparts

It is remarkable that in non-metaphorical uses, zagruzit' favors the Theme-Object construction. However, in metaphorical contexts, it is skewed towards the Goal-Object construction. The Locative Alterna- 
tion among metaphorical contexts of gruzit' 'load' and its perfective counterparts is presented in Table 4 (on the next page) and Figure 4 below:

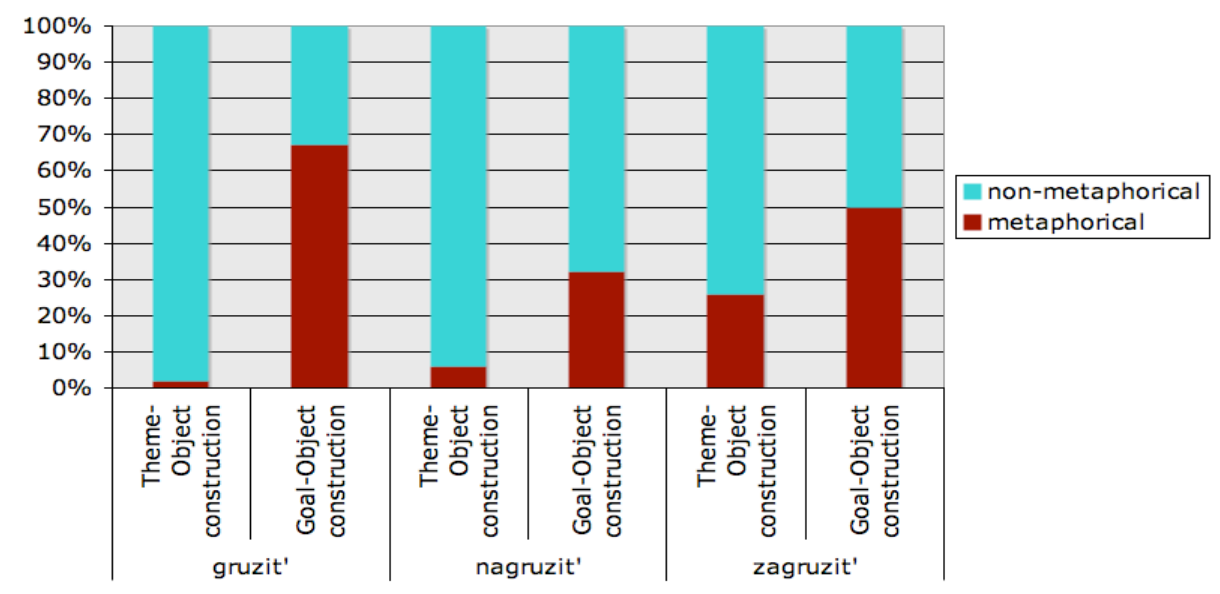

Figure 4. Locative alternation among metaphorical contexts of gruzit' 'load' and its perfective counterparts.

In the case of pogruzit', metaphorical contexts are extensions of the meaning 'submerge, sink' rather than the 'load' meaning of the verb. The first participant (Theme), represented by a direct object, usually denotes a person, whereas the second participant (Goal) marks the state (dream, trans, fear, etc.) into which the first participant is placed, as in example (33) below:

(33) On povernul nazad, ottolknulsja neskol'ko raz, he $_{N O M}$ turned back pushed-off few fCC $_{\text {times }}$ GEN i skorost', narastaja, pogruzila ego opjat' and speed $_{N O M}$ accelerating sank him $_{A C C}$ again v mečtu. into dream $A C C$

'He turned back, pushed off a few times and the growing speed submerged him again into a dream.'

The state here serves as the metaphorical CONTAINER and cannot be omitted. 
Table 4. Locative Alternation among Metaphorical Contexts of gruzit' 'Load' and Its Perfective Counterparts

\begin{tabular}{|c|c|c|c|c|c|c|c|c|c|c|}
\hline \multirow{3}{*}{$\begin{array}{l}\text { Active } \\
\text { forms } \\
\text { only }\end{array}$} & \multicolumn{4}{|c|}{ Theme-Object construction } & \multicolumn{6}{|c|}{ Goal-Object Construction } \\
\hline & \multicolumn{2}{|c|}{$\begin{array}{c}\text { non- } \\
\text { metaphorical }\end{array}$} & \multicolumn{2}{|c|}{ metaphorical } & \multirow{2}{*}{$\begin{array}{l}\text { Total } \\
\text { Theme- } \\
\text { Object } \\
\text { construction }\end{array}$} & \multicolumn{2}{|c|}{$\begin{array}{c}\text { non- } \\
\text { metaphorical }\end{array}$} & \multicolumn{2}{|c|}{ metaphorical } & \multirow{2}{*}{$\begin{array}{l}\text { Total Goal- } \\
\text { Object } \\
\text { construction }\end{array}$} \\
\hline & $\begin{array}{l}\text { raw } \\
\text { fr. }\end{array}$ & $\begin{array}{l}\text { relative } \\
\text { fr. }\end{array}$ & $\begin{array}{l}\text { raw } \\
\text { fr. }\end{array}$ & $\begin{array}{l}\text { relative } \\
\text { fr. }\end{array}$ & & $\begin{array}{l}\text { raw } \\
\text { fr. }\end{array}$ & $\begin{array}{l}\text { relative } \\
\text { fr. }\end{array}$ & $\begin{array}{l}\text { raw } \\
\text { fr. }\end{array}$ & $\begin{array}{l}\text { relative } \\
\text { fr. }\end{array}$ & \\
\hline gruzit' & 176 & $98 \%$ & 4 & $2 \%$ & 180 & 23 & $33 \%$ & 46 & $67 \%$ & 69 \\
\hline nagruzit' & 32 & $94 \%$ & 2 & $6 \%$ & 34 & 76 & $68 \%$ & 35 & $32 \%$ & 111 \\
\hline zagruzit' & 70 & $74 \%$ & 24 & $26 \%$ & 94 & 57 & $50 \%$ & 57 & $50 \%$ & 114 \\
\hline pogruzit' & 226 & $89 \%$ & 27 & $11 \%$ & 253 & 1 & $0 \%$ & 0 & $0 \%$ & 1 \\
\hline
\end{tabular}


Although we can see that metaphorical uses are attested for both constructions (Theme-Object and Goal-Object), alternations within the same metaphor type are not common. The metaphor type is represented by a specific combination of Themes and Goals. For instance, if we deal with the metaphor HUMAN (GOAL) + INFORMATION (THEME) mentioned earlier, where humans serve as metaphorical containers for information, the Goal-Object construction is most common; see examples (10) and (17). On the other hand, in the case of COMPUTER/ELECTRONIC DEVICE (GOAL) + INFORMATION (THEME) metaphor, the Theme-Object construction is highly preferred; see examples (34) and (35):

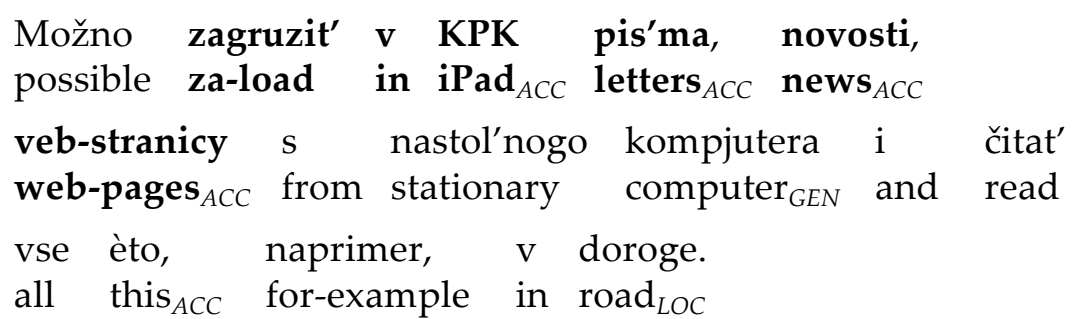

'You can upload letters, news, web-pages into iPad from your stationary computer and read all this, for instance, while travelling.'

\section{Theme-Object construction with an omitted Goal:}

(35) Ja begom kinulsja domoj i, ne razdevajas', $\mathrm{I}_{N O M} \operatorname{run}_{I N S T}$ threw-self home and not having-undressed vključil komp'juter, zagruzil èlektronnuju kartu turned-on computer $A C C$ loaded electronic map mCC goroda. town $_{G E N}$ 'I raced home and turned on my computer without even taking my coat off and downloaded the electronic map of the town.'

We find only few exceptions from the general tendency: two cases (out of 12) with the Theme-Object construction for HUMAN + INFORMATION (example (36)), and one case (out of 21) with the GoalObject construction for COMPUTER/ELECTRONIC DEVICE + INFORMATION (example (37)): 
(36) A vot zagruzil začem-to $\mathbf{v}$ svoj bednyj and here $z \boldsymbol{a}$-loaded for-some-reason in $\mathrm{my}$ poor mozg ešče šest' sot stranic. brain $_{A C C}$ another six hundred hCC $_{\text {pages }}$ GEN

'And for some reason I loaded into my poor brain another 600 pages.'

(37) Staralis' zagruzit' komp'jutery v dve smeny. tried $z \boldsymbol{a}$-load $_{I N F}$ computers $_{A C C}$ in two shifts ${ }_{A C C}$

'They tried to make computers work in two shifts.'

However, example (36) presents the person's brain and not the person in general as the Goal, which makes the analogy between humans and computers stronger and hence allows for the choice of the Theme-Object construction. Thus, it appears that although the two metaphor types seem to be parallel, in reality, they behave differently in terms of formal representations, which means that the original properties of the target domain are preserved.

One more important conclusion that the data suggest is that metaphorical extensions, in general, are more frequent within the Goal-Object construction. The relationship between the Goal-Object construction and metaphorical uses is statistically significant and has a robust effect size: $\chi$-squared $=145.3065, \mathrm{df}=1$, p-value $<2.2^{\mathrm{e}-16}$, Cramer's $\mathrm{V}=$ 0.412008 . The data is summarized in Table 5:

Table 5. Correlation between Constructions and Metaphor within the 'load' Verbs

\begin{tabular}{lcc}
\hline & $\begin{array}{c}\text { Theme-Object } \\
\text { construction }\end{array}$ & $\begin{array}{c}\text { Goal-Object } \\
\text { construction }\end{array}$ \\
\hline Non-metaphorical & 504 & 157 \\
metaphorical & 57 & 138 \\
\hline \hline
\end{tabular}

Finally, we need to look at the relationship between reduction and metaphorical extensions. The frequency of reduction among metaphorical contexts of the 'load' verbs is given below in Table 6 (on the next page) and Figure 5: 
Table 6. Reduction among Metaphorical Contexts of the 'load' Verbs

\begin{tabular}{|c|c|c|c|c|c|c|c|c|c|c|}
\hline \multirow{3}{*}{$\begin{array}{l}\text { Active } \\
\text { forms } \\
\text { only }\end{array}$} & \multicolumn{4}{|c|}{ Non-metaphorical contexts } & \multicolumn{6}{|c|}{ Metaphorical contexts } \\
\hline & \multicolumn{2}{|c|}{$\begin{array}{c}\text { full } \\
\text { constructions }\end{array}$} & \multicolumn{2}{|c|}{$\begin{array}{c}\text { reduced } \\
\text { constructions }\end{array}$} & \multirow{2}{*}{$\begin{array}{l}\text { Total non- } \\
\text { metaphorical } \\
\text { contexts }\end{array}$} & \multicolumn{2}{|c|}{$\begin{array}{c}\text { full } \\
\text { constructions }\end{array}$} & \multicolumn{2}{|c|}{$\begin{array}{c}\text { reduced } \\
\text { constructions }\end{array}$} & \multirow{2}{*}{$\begin{array}{l}\text { Total } \\
\text { metaphorical } \\
\text { contexts }\end{array}$} \\
\hline & $\begin{array}{l}\text { raw } \\
\text { fr. }\end{array}$ & $\begin{array}{l}\text { relative } \\
\text { fr. }\end{array}$ & $\begin{array}{l}\text { raw } \\
\text { fr. }\end{array}$ & $\begin{array}{l}\text { relative } \\
\text { fr. }\end{array}$ & & $\begin{array}{l}\text { raw } \\
\text { fr. }\end{array}$ & $\begin{array}{l}\text { relative } \\
\text { fr. }\end{array}$ & $\begin{array}{l}\text { raw } \\
\text { fr. }\end{array}$ & $\begin{array}{l}\text { relative } \\
\text { fr. }\end{array}$ & \\
\hline gruzit' & 107 & $57 \%$ & 79 & $43 \%$ & 186 & 30 & $60 \%$ & 20 & $40 \%$ & 50 \\
\hline nagruzit' & 75 & $68 \%$ & 35 & $32 \%$ & 110 & 22 & $59 \%$ & 15 & $41 \%$ & 37 \\
\hline zagruzit' & 90 & $71 \%$ & 37 & $29 \%$ & 127 & 36 & $44 \%$ & 45 & $56 \%$ & 81 \\
\hline pogruzit' & 175 & $77 \%$ & 52 & $23 \%$ & 227 & 27 & $100 \%$ & 0 & $0 \%$ & 27 \\
\hline
\end{tabular}




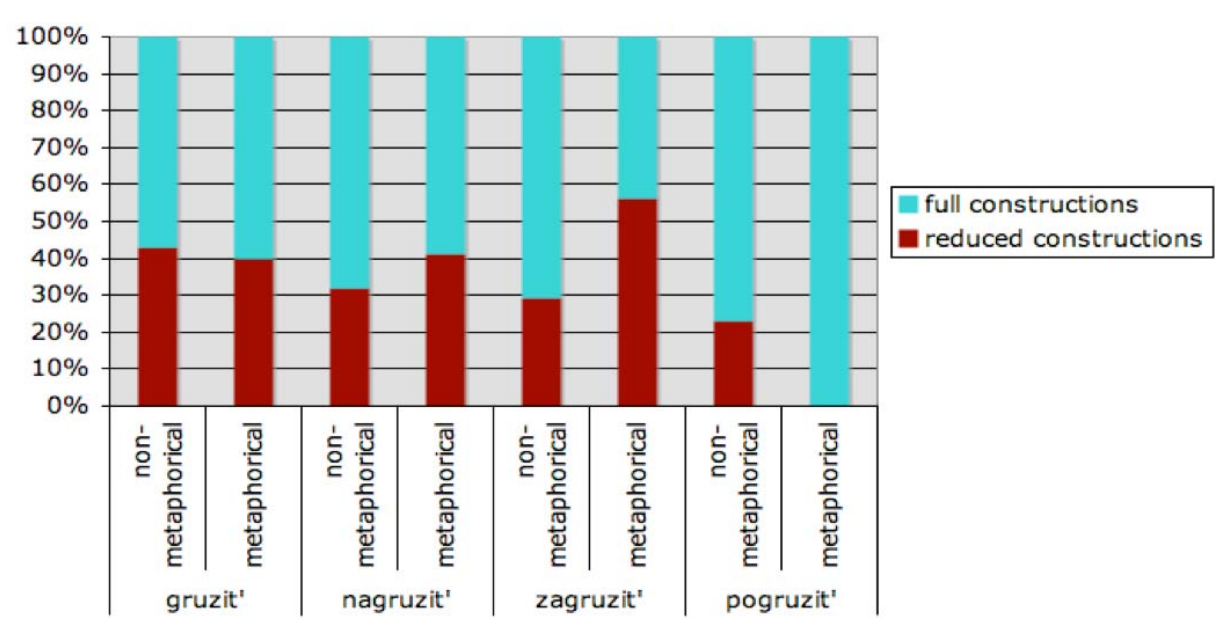

Figure 5. Reduction among metaphorical contexts of the 'load' verbs

As can be seen from Figure 5, the proportion of reduced constructions for the unprefixed verb gruzit' is almost the same in non-metaphorical and metaphorical contexts. However, reduced constructions show higher frequency within metaphorical contexts when the prefixes $n a$ - or $z a$ - are added, with $z a$ - having the strongest affinity for reduced constructions: $\chi$-squared $=13.3722, \mathrm{df}=1$, p-value $=0.0002554$, Cramer's V $=0.2535536$.

Thus, we can say that the data from the Russian 'load' verbs suggests that in certain cases (mostly, with the prefix $z a-$ ) metaphorical extensions are strongly associated with reduction. Furthermore, we have seen that the Goal-Object construction is more susceptible to metaphor than the Theme-Object construction. The Goal-Object construction focuses on the changes that the Goal undergoes, and this allows for the frequent omission of the Theme.

In addition, the data allow us to draw some conclusions which outline the relation between formal representation of metaphor and conceptual metaphor. On the one hand, metaphorical uses of gruzit' 'load' show minimal alternation, which supports the idea that not all properties of the source domain are borrowed to the target domain in the process of mapping and that metaphor presupposes specification. On the other hand, we have support for the claim that the original properties of the target domain are preserved: ' $z a$-loading the com- 
puter' differs from 'za-loading the person': zagruzit' komp'juter ' $z a$-load a computer' entails the meaning 'boot a computer', i.e., make it work, whereas zagruzit' čeloveka 'za-load a person' means 'puzzle a person', i.e., prevent him/her from functioning appropriately.

\section{Conclusion}

My analysis of the Russian Locative Alternation verbs lends strong support to the hypothesis that metaphorical and non-metaphorical content find different expression on the constructional level. As we saw in the case of sypat' 'strew', metaphorical extensions show a strong relationship with elaboration (interactions of constructions), where $72 \%$ of all metaphorical uses of 'strew' are attested in the Hybrid construction. The case study of the 'load' verbs suggests that metaphorical extensions can also be marked by reduction. Reduction in metaphorical contexts is more strongly associated with zagruzit' 'load' (56\% of metaphorical extensions here are reduced). On the one hand, this would indicate that a change in structure leads to a change in meaning; on the other hand, in both cases we are dealing with statistical tendencies where metaphor is associated with a certain construction.

Furthermore, the case study of the 'load' verbs indicates that different prefixes behave differently in terms of metaphorical extensions even when they are used to form perfective partner verbs. The metaphoric propensity of the prefix is attributed to its semantic network. In the case of the 'load' verbs, $z a$ - is the most common choice for metaphorical extensions (39\% of all the uses of zagruzit' load' are metaphorical as opposed to $25 \%$ for nagruzit' and $11 \%$ for pogruzit'). When we are dealing with constructional alternations, the data is always skewed, i.e., the verb always has a stronger preference for one of the constructions. However, it has been shown that metaphorical extensions do not always retain the same preferences for constructions as non-metaphorical uses. Conventional metaphorical patterns can skew the frequency in favor of one particular construction (cf. the case with zagruzit' 'load' which shows a preference for the Theme-Object construction in non-metaphorical uses, and a preference for the Goal-Object construction in metaphorical uses, which makes the overall distribution of the two constructions almost equal).

In addition, we can draw some conclusions concerning the relation between conceptual metaphor and its formal representations. Not all 
properties of the source domain are borrowed to the target domain in the process of mapping. Hence we rarely find alternation in metaphorical contexts within the same metaphoric pattern, for instance the HUMAN + INFORMATION/HUMAN IS A COMPUTER metaphor is attested mainly in the Goal-Object construction. The Locative Alternation constructions have different degrees of correlation with metaphor. Thus, the Goal-Object construction shows a higher frequency of metaphorical extensions. The original properties of the target domain are partially preserved. As shown in section 4.2, different meanings are entailed in 'loading a person' and 'loading a computer', where the former presupposes booting a computer, i.e., making it function, and the latter entails the meaning of puzzling someone, i.e., preventing him/her from functioning appropriately.

The two case studies presented here lead us into the discussion of more general theoretical issues concerning the relation between aspect and metaphor. It appears that reduction is more characteristic of the prefixed perfective verbs. As shown in previous research, transitivity has a strong relationship with resultative verbs (Hopper and Thompson 1980) ${ }^{10}$ and prefixed verbs, even prefixed imperfectives, denote an action "with a consideration of its result" (Veyrenc 1980: 176). Prefixed verbs are more strongly oriented towards objects than unprefixed verbs: prefixes can serve as object markers, making it possible to omit the object when the meaning is clear from the context. Thus, one would expect reduction to be more natural for prefixed verbs. Elaboration is more characteristic of the unprefixed imperfective verbs where we find not only omission of some arguments, i.e., reduction, but also a reorganization of the structure. However, this relationship between aspect and metaphor needs to be tested on a larger number of verbs.

\footnotetext{
10 "An action viewed from its endpoint, i.e., a telic action, is more effectively transferred to a patient than one not provided with such endpoint" (Hopper and Thompson 1980: 252).
} 


\section{References}

Croft, William and David Alan Cruse. (2004) Cognitive linguistics. Cambridge: Cambridge University Press.

Cubberly, Paul V. (1982) "On the 'empty' prefixes in Russian”. Russian language journal 36: 14-30.

Deignan, Alice. (2005) Metaphor and corpus linguistics. Amsterdam: John Benjamins.

Evgen'eva, A. P., ed. (1999) Malyj akademičeskij slovar'. Moscow: Russkij jazyk.

Fauconnier, Gilles and Mark Turner. (2002) The way we think: Conceptual blending and the mind's hidden complexities. New York: Basic Books.

_. (2008) "Rethinking metaphor". Ray Gibbs, ed. Cambridge handbook of metaphor and thought. New York: Cambridge University Press.

Fillmore, Charles F. (2008) "Border conflicts: FrameNet meets Construction Grammar". Unpublished ms., University of California, Berkeley. [Presented as a plenary talk at Euralex 2008.]

Firth, John R. (1957) "A synopsis of linguistic theory 1930-1955". Studies in linguistic analysis. Oxford: Blackwell, 1-32.

Goldberg, Adele E. (1995) Constructions: A Construction Grammar approach to argument structure. Chicago: University of Chicago Press.

Hopper, Paul J. and Sandra A. Thompson. (1980) "Transitivity in grammar and discourse". Language 56(2): 251-99.

Janda, Laura A. and Valery D. Solovyev. (2009) "What constructional profiles reveal about synonymy: A case study of Russian words for SADNESS and HAPPINESS". Cognitive linguistics 20: 367-93.

Lakoff, George. (1993) "The contemporary theory of metaphor". Andrew Ortony, ed. Metaphor and thought. Cambridge: Cambridge University Press.

Lakoff, George and Mark Johnson. (1980) Metaphors we live by. Chicago: University of Chicago Press.

Marantz, Alec. (1984) On the nature of grammatical relations. Cambridge, MA: MIT Press. 
Nichols, Johanna. (2008) "Prefixation and the locative alternation in Russian contact verbs". Presentation at the annual conference of the American Association of Teachers of Slavic and East European Languages, San Francisco.

Ožegov, S. I. and N. Ju. Švedova. (2001) Slovar' russkogo jazyka. Moscow: Russkij jazyk.

Sokolova, Svetlana. (2012) Asymmetries in linguistic construal: Russian prefixes and the locative alternation. Ph.D. dissertation, University of Tromsø.

Sokolova Svetlana, Olga Lyashevskaya, and Laura A. Janda (2012) “The locative alternation and the Russian 'empty' prefixes: A case study of the verb gruzit' 'load'". Stefan Th. Gries and Dagmar Divjak, eds. Frequency effects in language: Frequency effects in language representation. Vol. 2. Berlin: Mouton de Gruyter, 51-86. [Trends in Linguistics, 244.2.]

Steen, Gerard J. (2007) Finding metaphor in grammar and usage: A methodological analysis of theory and research. Amsterdam: John Benjamins.

Steen Gerard J., Aletta G. Dorst, J. Berenike Herrmann, Anna. Kaal, Tina Krennmayr, and Trijntje Pasma. (2010) A method for linguistic metaphor identification: From MIP to MIPVU. Amsterdam: John Benjamins.

Stefanowitsch, Anatol. (2006) "Words and their metaphors: A corpusbased approach". Anatol Stefanowitsch and Stefan Th. Gries, eds. Corpus-based approaches to metaphor and metonymy. Berlin: Mouton de Gruyter, 61-105. [Trends in Linguistics, 171.]

Stefanowitsch, Anatol and Stefan Th. Gries. (2003) "Collostructions: Investigating the interaction of words and constructions". International journal of corpus linguistics 8: 209-43.

_. (2005) "Covarying collexemes". Corpus linguistics and linguistic theory 1: 1-43.

Turner, Mark B. (1995) "As imagination bodies forth the forms of things unknown". Pragmatics and cognition 3(1): 179-85.

-. (2005) "The literal versus figurative dichotomy". Seana Coulson and Barbara Lewandowska-Tomaszczyk, eds. The literal and nonliteral in language and thought. Frankfurt: Peter Lang, 25-52. 
Turner, Mark B. (2008) "Frame blending". Rema Rossini Favretti, ed. Frames, corpora, and knowledge representation. Bologna: Bolonia University Press, 13-32.

Veyrenc, Jacques. (1980) "Un problème de formes concurrentes dans l'économie de l'aspect verbal en russe: Imperfectifs premiers et imperfectifs seconds". Études sur les verbe russe. Paris: Institut d'etudes slaves, PP?

Department of Language and Linguistics University of Tromsø

NO-9037 Tromsø

Norway

svetlana.sokolova@uit.no
Received: August 2012

Revised: January 2013 